International Journal of Instruction e-ISSN: 1308-1470 • www.e-iji.net

Article submission code: 20201229024812

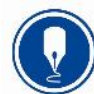

January $2022 \bullet$ Vol.15, No.1

p-ISSN: 1694-609X

pp. 347-364

Received: 29/12/2020

Revision: 28/06/2021
Accepted: 22/07/2021

OnlineFirst: $24 / 10 / 2021$

\title{
The Impact of Inclusive Islamic Education Teaching Materials Model on Religious Tolerance of Indonesian Students
}

\section{Munawar Rahmat}

Assoc. Prof., Indonesia University of Education, Bandung, Indonesia, munawarrahmat.pai@upi.edu

\section{Wildan Bin H. M. Yahya}

Assoc. Prof., Bandung Islamic University, Bandung, Indonesia,

wildanyahya@unisba.ac.id

The purpose of this study is to examine the effectiveness of the inclusive PAI teaching material model on religious tolerance and eradication of radicalism in Indonesian students. Survey institutions show that religious minorities experience violations of freedom of religion and belief. Various studies indicate that about $50 \%$ of students are intolerant and have more contact with Takfiri Salafis. The negative social media posts by students leads to the negative publicity against Islamic Religious Education (PAI) lecturers. Although the PAI course aims to build students' religiosity and tolerance, it contains minimal relevant content. A sample of 460 students, specifically 230 experimental and 230 control classes, were tested using the Quasi-experimental method. The results showed that inclusive PAI teaching material is more effective in increasing religious tolerance and reducing radicalism. Therefore, PAI lecturers need to adopt this method to increase students' tolerance.

Keywords: PAI subject, PAI teaching materials, religious tolerance, schools, students

\section{INTRODUCTION}

\section{Indonesian Society and Student Intolerance is Very High}

Religious tolerance refers to an inclusive attitude in the recognition of rights and freedom of religion (Mirchandani \& Tastsoglou, 2000). According to Little (2017) and Imarah (1999), tolerance is the detention of coercion or physical violence against different religious groups and schools. Religious tolerance refers to the behavior of approving religious differences in a plural society without any prejudice or discrimination, even when one has the power to prevent prosperity and harmony in society (Talib et al., 2013). It is mutual respect between adherents of different religions and schools, which is shown by allowing people to worship freely without criticism, prohibition and disturbance. Contrastingly, intolerance refers to the exclusive attitude of considering one's religious beliefs and schools as right and all others as wrongs.

Citation: Rahmat, M., \& Yahya, M. W. B. H. M. (2022). The impact of inclusive islamic education teaching materials model on religious tolerance of Indonesian students. International Journal of Instruction, 15(1), 347-364. https://doi.org/10.29333/iji.2022.15120a 
According to the Setara Institute, religious minorities in Indonesia were the biggest victims of acts and incidents of violations of freedom from 2007 to 2016. In 2014, 2015 and 2019, there were 134, 197 and 208 violations cases in various parts of Indonesia (Gabrillin, 2016; Marshall, 2018). This is in line with results conveyed by the US commission on international religious freedom (USCIRF) (Abdillah, 2016). Indonesian National Human Rights Commission (Komnas-HAM, 2018) stated that complaints received by this institution increased from 74, 87 and 97 in 2014, 2015 and 2016. Although there was a significant decrease in 2017, violations in 2018 and 2019 were 21 and 29 (Komnas-Ham, 2020).

According to BBC-News 2011, a survey of 1000 students from 100 private and public schools showed that nearly $50 \%$ of the respondents approved religious radical action. A different survey conducted in 2017 and 2018 showed that these conditions had increased. The Islamic and community studies center reported that in 1,859 students and 322 lecturers, 55\% and 62\% agreed that Muslims were wrong in denying regional and national leadership positions to non-Muslims. Koran-Tempo, 2019 stated that religious textbooks in Islamic Kindergartens had radical nuances.

Almost 50\% of 500 high school students in big cities were religious intolerant in 2015 and 2016 (E. Firdaus \& Rahmat, 2016). Although Islamic-based schools in West Java have succeeded in developing religiosity, they fail on intolerance. Similarly, Christianbased schools succeed in building tolerance but fail in religiosity. Only the state junior high schools have succeeded in building religiosity and tolerance (Rizal \& Rahmat, 2019). In Rahmat (2012), nearly 50\% of the 1,000 students in west java have an exclusive religious mindset. Firdaus and Rahmat (2020) stated almost 75\% of the study respondents viewed other religious followers as infidels who would go to hell, while Muslims were believers and surgeons. Furthermore, 15\% of the 380 UPI and UNSIL students accepted the presence of minority groups in Islamic schools, while 52\% and $33 \%$ were either neutral or against. According to Yahya \& Rahmat (2021), 50\% of 300 UPI and UNISBA students are intolerant.

\section{PAI Textbooks have a minimal content of tolerant characters}

The right teaching material is essential in the design and effectiveness of the teaching process. According to (Groccia, 2012), accuracy, level of difficulty, organization, and meaning of teaching materials should match the desired learning outcomes, students, and instructor's skills. Islamic Religion Education (PAI) is a compulsory subject in the Indonesian Higher Education curriculum. These courses develop students' faith, character, and respect and tolerance for religious differences (Decree of the DirectorGeneral of Higher Education, 2020). However, only 1 out of 11 government-published PAI textbook themes contain religious tolerance (Nurwardani et al., 2016). In PAI textbooks published by tertiary institutions, only 1 out of 10-15 themes contain religious tolerance (Tim-Dosen-PAI-UPI, 2016; Tim-Penyusun, 2015; Zakiah et al., 2015; Mardani, 2017).

Students are more influenced by intolerant Islamic social media posts and activists (Anshori, 2019; Wahyudi, 2018; Addariny, 2015). For instance, the Takfiri Salafis - an 
Islamic extremist group fighting for the upholding of Islamic law-is anti-Shi'a and often accuses moderate Muslims of being kafir (Zenna \& Pieri, 2017; Olsson, 2020; Amal, 2020). They often enter the campus and influence Islamic activist students by playing videos of hate speech against Shi a, moderate Muslims, and non-Muslims. Furthermore, they also disbelieve moderate PAI lecturers, emphasizing not to listen to his lecture. In case he preaches on Friday at the campus mosque, immediately move to another mosque. According to Kevin Novel Kurniawan, this is the hidden curriculum (Kurniawan, 2018).

Students' tolerance is influenced by Islamic teachings from social media and religious communities. The PAI curriculum has weaknesses, such as minimal tolerant character and confounding factors that affect one's beliefs. Furthermore, messages and videos spread by Takfiri Salafis and social media spread intolerant attitudes among students. Therefore, systems need to develop inclusive PAI teaching materials with tolerant and anti-radicalism characters to instill better values. Teaching materials need to directly refer to the Al-Qur'ān, sahih hadiths, and authoritative scholarly institutions.

To fill in the gaps in PAI teaching materials that contain intolerant and anti-radicalism characters, 10 themes inclusive PAI teaching materials for 10 lectures were compiled. The accusation of being infidels is suspected to be the main cause of religious intolerance. Students are trained through the digital thematic method of the Qur'ān to limit their mistakes (Rahmat \& Fahrudin, 2018a). Specifically, they are asked to install digital Qur`ān ver 3.1 (Digital Al-Qur’ān and its translation published by the Indonesian Ministry of Religion). Afterwards, they are required to analyze all the verses of the Qur’ān about Judaism, Christianity, Sabi in, and Ahl al-Kitab. According to Q 2/AlBaqarah 62, Q 3/Ali Imran 113-114, and Q 5/Al-Maidah 69, there are both believers and pious (Qur'ān, 2013), with many scholars referring to these holy verses (Riḍā, 1990; Farah, 2016; Ahmad, 2006; Nasution, 2006; Ulfa, 2013). However, Q 2/Al-Baqarah 105, 109, Q 3/Ali Imran 72, 100, Q 4/Al-Nisa 51, Q 59/Al-Hashr 2, 11, and Q 98/AlBayyina 1, 6 states that many of them are disbelievers (Qur’ān, 2013). This means that in the sight of Allah, there are non-Muslims who are disbelievers and believers, and that Muslims are not necessarily believers. The Prophet Muhammad stated that only one of the 73 Islamic groups will enter heaven (Abudawud, 2013; Tirmidzi, 2013; Ibnumajah, 2013).

They accused minority schools of Islam of being infidel (Abdillah, 2016; Rahmat et al., 2021), even though this accusation was prohibited by Prophet SAW because it was a risk that God would assign an infidel to the accuser (Bukhari, 2013; Muslim, 2013). The Amman treatise defines 8 groups of Muslims, including the Four Sunni Schools, Shì Imamiya, and Shi'a Zaidiya (Wikipedia, 2020). According to the authoritative institution of Indonesian ulama, Shi'a is not heretical, it is still in Islamic circles (Muhtarom, 2017). The results of the Al-Azhar conference prohibit takfir by asserting that in case someone's words contain 99 features of disbelief but there is still one characteristic of Islam, the person should not be accused of being kafir (Conference-AlAzhar, 2020). 


\section{METHOD}

\section{Research design}

The purpose of this study is to examine the effectiveness of the inclusive PAI teaching material model on religious tolerance and eradication of radicalism in students using quasi-experimental design. The experimental classes used the inclusive PAI teaching material model, while the control group used conventional teaching materials. Research results were obtained from a pre-test conducted in August and a post-test completed in November 2020. Respondents were tested after 10 times lectures conducted using the two teaching materials.

\section{Population and Sample Selection}

This study's population consisted of 3099 students or 83 classes from the Indonesia University of Education (UPI) who had enrolled for the PAI course for the odd semester of 2020-2021. All other characteristics before attending PAI courses were relatively similar. For instance, $66 \%$ of the total population could not read the Al-Qur'ān, while $34 \%$ could read almost evenly.

The sample was determined purposively by selecting classes where the lecturers were voluntarily willing to use the inclusive PAI teaching material model. Both the control and experimental groups had a total of 6 classes ( 230 students) each that studied the same, as shown in Table 2.

Table 1

Sample Selection, study program, experiment classes, control classes

\begin{tabular}{|c|c|c|c|c|c|}
\hline \multirow[t]{2}{*}{ No. } & \multirow[t]{2}{*}{ Study program } & \multicolumn{2}{|c|}{ Experiment classes } & \multicolumn{2}{|c|}{ Control classes } \\
\hline & & $\Sigma$ classes & $\Sigma$ students & $\sum$ classes & $\Sigma$ students \\
\hline 1 & Social Sciences & $\mathrm{B}$ & 40 & A & 38 \\
\hline 2 & Natural Sciences & $\mathrm{A}$ & 36 & $\mathrm{~B}$ & 38 \\
\hline 3 & Language & $\mathrm{A}$ & 37 & $\mathrm{~B}$ & 36 \\
\hline 4 & Technical & $\mathrm{A}$ & 39 & $\mathrm{~B}$ & 41 \\
\hline 5 & Nursing & $\mathrm{D}$ & 37 & $\mathrm{C}$ & 37 \\
\hline \multirow[t]{2}{*}{6} & Sports & $\mathrm{B}$ & 41 & A & 40 \\
\hline & Total & 6 classes & 230 students & 6 classes & 230 students \\
\hline
\end{tabular}

Table 1 shows that the research sample was 12 classes from $83(14.5 \%)$ or 460 students out of 3,099 (14.8\%).

\section{Research Instruments}

The research instrument was an inventory of religious tolerance in the form of Yes - No for each item. A total of 50 items were compiled with 25 items measuring religious tolerance towards religions outside Islam. The other 25 items measure religious tolerance towards Islamic minorities, particularly Shi'ites and Ahmadiya. Importantly, 25 items were positive statements, while the other 25 were negative. A Delphy test was conducted on 5 experts who approved 44 items, which were tested for validity and reliability through the IBM SPSS Statistics 26. The validity was tested through Pearson's two-tiled correlate bivariate analysis, while reliability used the alpha scale analysis model. The results showed that 42 items are valid or 38 items were significant at alpha 0.01 while 4 items scored 0.05 . The reliability of $r=0.94$ was significant at 
alpha 0.01 . Because the other 2 items were insignificant, a total of 42 items were used to measure student religious tolerance. Therefore, religious tolerance towards other religions and minority Islamic schools were measured by 21 items each. The indicator is student acceptance/rejection of adherents of other religions and minority Islamic schools as

1. friends,

2. neighbors,

3. regents/mayors, governors, and high state officials,

4. their religious activities in the respondent's environment,

5. the establishment of their places of worship in the respondent's area,

6. their faith status, are they infidels and experts in hell, or can they also believe and go to heaven? Examples of items areas in the following table.

Table 2

Examples of positive and negative items on research instruments of religious tolerance

\begin{tabular}{llll}
\hline No. & Yes & No & Statement \\
\hline $1(-)$ & $\ldots$ & $\ldots$ & Heaven is only reserved for Muslims. \\
\hline $2(+)$ & $\ldots$ & $\ldots$ & Faithful and humble Non-Muslims can enter heaven. \\
\hline $3(-)$ & $\ldots$ & $\ldots$ & Every Christian is heathen because of the Trinity theology which teaches of 3 Gods. \\
\hline $4(+)$ & $\ldots$ & $\ldots$ & $\begin{array}{l}\text { A Muslim must not accuse people from the same faith, especially an Islamic group, } \\
\text { of being kafirs. }\end{array}$ \\
\hline $5(-)$ & $\ldots$ & $\ldots$ & Ahmadiya is not Islam. \\
\hline $6(+)$ & $\ldots$ & $\ldots$ & $\begin{array}{l}\text { I support the Amman Treatise which states that Shi a Imamiya and Zaidiya are the } \\
\text { same as Sunnis and are equally Islamic. }\end{array}$ \\
\hline Etc & $\ldots$ & $\ldots$ & \\
\hline
\end{tabular}

\section{Data Analysis}

The normality test in this study used the Skewness-Kurtosis test method. This method is advantageous because it makes decisions on a normality test when used on data with an average value smaller than the standard deviation (Oktaviani \& Notobroto, 2014). Skewness-Kurtosis test decision making regarding normally distributed data is used. In case the two $t$-values, both $t_{\text {skew }}$ and $t_{\text {kurt }}$, are in the range of values $-1.96 \leq t \leq 1.96$, the data is normally distributed. However, where both or only one of the $t_{\text {skew }}$ or $t_{\text {kurt }}$ values are not in this range, the data is not normally distributed (Kuntoro, 2011).

The calculation of the Skewness-Kurtosis test used the IBM Statistical Package for the Social Sciences (SPSS) version 24 for windows. Based on Table 3, the normality test results show that the pre-test and post-test skewness values of tolerance for religions outside Islam are 0.100 and 0.195 , respectively $(-1.96 \leq \mathrm{t} \leq 1.96)$. The kurtosis values were -0.477 and $-0.704(-1.96 \leq t \leq 1.96)$, respectively. Furthermore, the skewness pretest and post-test tolerance scores for minority schools were 0.476 and 0.181 , respectively $(-1.96 \leq \mathrm{t} \leq 1.96)$, while the kurtosis values were -0.474 and $-0.629(-1.96$ $\leq \mathrm{t} \leq 1.96)$. Overall, the pre-test and post-test on students' religious tolerance towards religions outside Islam showed that the data were normally distributed. The pre-test and post-test on student religious tolerance towards minority Islamic schools are also normally distributed and could be continued at the next stage. 
Table 3

The results of normality test with the Skewness-Kurtosis method

\begin{tabular}{llllll}
\hline \multirow{2}{*}{ No. } & \multirow{2}{*}{$\begin{array}{l}\text { Normality test using the Skewnesss-Kurtosis } \\
\text { Method }\end{array}$} & \multicolumn{2}{c}{$\begin{array}{c}\text { Skewness } \\
\left(\mathrm{t}_{\text {skew }}\right)\end{array}$} & \multicolumn{2}{c}{$\begin{array}{c}\text { Kurtosis } \\
\left(\mathrm{t}_{\mathrm{kurt}}\right)\end{array}$} \\
\cline { 3 - 6 } & & Pre-test & Post-test & Pre-test & Post-test \\
\hline 1. & Tolerance towards non-Islamic religions & 0.100 & 0.195 & -0.477 & -0.704 \\
\hline 2. & Tolerance towards minority Islamic schools & 0.476 & 0.181 & -0.474 & -0.629 \\
\hline
\end{tabular}

Data was analyzed using comparative techniques between experimental and control classes and post and pre-test results, specifically the IBM SPSS Statistics 24 with Paired Samples (t-test).

\section{FINDINGS}

\section{The profile of student religious tolerance towards religions outside Islam}

Table 4

The results of pre-test and post-test (\%) of students' religious tolerance in experimental and control classes towards religions outside of Islam

\begin{tabular}{|c|c|c|c|c|}
\hline \multirow[t]{2}{*}{ Items of tolerance towards non-Islamic religions } & \multicolumn{2}{|c|}{$\begin{array}{l}\text { Experiment } \\
\text { classes }(\%)\end{array}$} & \multicolumn{2}{|c|}{$\begin{array}{l}\text { Control } \\
\text { classes }(\%)\end{array}$} \\
\hline & Pre-test & Post-test & Pre-test & Post-test \\
\hline $\begin{array}{l}\text { 1. The main character of a believer is humility and not pride. Such non- } \\
\text { Muslims can be believers. }\end{array}$ & 49.1 & 80.9 & 50.9 & 53.5 \\
\hline $\begin{array}{l}\text { 2. The main character of the non-believers is arrogance or pride. A } \\
\text { Muslim with the same traits could be considered an infidel. }\end{array}$ & 69.6 & 85.7 & 71.3 & 73.0 \\
\hline Heaven is only reserved for Muslims. & 22.2 & 70.4 & 21.7 & 28.3 \\
\hline Non-Muslims will go to hell no matter how good their morals are. & 31.3 & 65.7 & 30.9 & 32.2 \\
\hline Muslims are automatically believers & 69.6 & 91.7 & 70.9 & 70.4 \\
\hline $\begin{array}{l}\text { 6. Non-Muslims, specifically Christians and Hindus are automatically } \\
\text { experts in hell. }\end{array}$ & 36.1 & 74.6 & 36.1 & 37.4 \\
\hline $\begin{array}{l}\text { 7. It could be that Christians, Buddhists, and other people of the } \\
\text { scriptures, some are believers }\end{array}$ & 60.4 & 87.4 & 59.1 & 60.9 \\
\hline 8. $\quad$ Non- Muslims who are faithful and humble can enter heaven. & 63.0 & 85.7 & 63.9 & 64.8 \\
\hline Non-Muslims should not be accused of being infidels. & 47.0 & 80.4 & 49.6 & 51.7 \\
\hline 10. Every Christian is heathen because of the Trinity theology (3 Gods). & 18.3 & 60.9 & 19.1 & 20.9 \\
\hline 11. Every Hindu is an infidel because of the Trimurti theology (3 Gods). & 18.7 & 60.0 & 17.0 & 17.4 \\
\hline $\begin{array}{l}\text { 12. People who are religious outside of Islam must reject the Apostolate of } \\
\text { the Prophet Muhammad. }\end{array}$ & 33.5 & 57.8 & 36.1 & 38.3 \\
\hline $\begin{array}{l}\text { 13. It could be Buddhists, Confucians, etc. who have noble morals are } \\
\text { believers in the sight. }\end{array}$ & 34.8 & 74.8 & 38.3 & 39.6 \\
\hline 14. I am willing to make friends with people of any religion. & 91.3 & 95.2 & 92.6 & 93.0 \\
\hline $\begin{array}{l}\text { 15. I do not want to be neighbors with Chinese Christians, Buddhists, or } \\
\text { Confucians. }\end{array}$ & 92.6 & 98.3 & 94.3 & 95.7 \\
\hline $\begin{array}{l}\text { 16. We do not allow other religions to commemorate for worship services } \\
\text { in our environment. }\end{array}$ & 94.8 & 94.8 & 90.0 & 93.0 \\
\hline $\begin{array}{l}\text { 17. We do not allow followers of other religions to build houses of worship } \\
\text { in our neighborhood. }\end{array}$ & 94.3 & 94.3 & 90.4 & 90.4 \\
\hline $\begin{array}{l}\text { 18. In my opinion, Christians or Confucians and any other non-Muslims } \\
\text { are allowed to run for regents/mayors/governors in Muslim areas. }\end{array}$ & 49.6 & 70.0 & 49.6 & 49.6 \\
\hline 19. [ will choose the best regional head regardless of religion & 32.6 & 48.7 & 31.7 & 34.3 \\
\hline $\begin{array}{l}\text { 20. I will vote for candidates for a regional head who are Muslims even } \\
\text { though their qualities are lower compared to other candidates }\end{array}$ & 30.9 & 37.8 & 30.9 & 35.2 \\
\hline 21. Some Muslims are believers while are infidels before Allah. & 86.5 & 93.0 & 85.7 & 86.1 \\
\hline
\end{tabular}

$\mathrm{n}$ experiment $=230$ students, $\mathrm{n}$ control $=230$ students 
Table 4 shows that before the PAI lecture conducted in August 20209 items in the experimental class and 10 in the control group received positive responses from more than $50 \%$ of the total respondents. After completion of the course in November 2020, all items in the experimental class and 13 in the control group received a positive response from more than $50 \%$ of the total students. The control class had 8 items with negative responses from more than half of the respondents, as shown below.

- Before the PAI lecture, more than half of the experimental and control class students responded positively to 9-10 Items, including 2, 5, 7-8, 14-17, and 21. Also, the control responded positively to item 1 . Conclusively, more than $50 \%$ of the total students accept that believers or infidels refer more to positive or negative characters, not to religious identity. Furthermore, students also want to be friends with Non-Muslims and allow them to build houses of worship in the neighborhood.

- Before the PAI lecture, more than half of the students in both groups responded negatively to 11-12 items, including $1,3,4,6,9-13$, and 18-20, except 1 in the control class first. Therefore, more than $50 \%$ of students that heaven and hell are related to religious identity. Heaven is only for Muslims, while other religions will go to hell. Also, students will not elect a non-Muslim regional leader even though qualities are of a better fit.

- After the PAI lecture, more than half of the experimental class students responded positively to all (21) items, while in the control group 8 questions had a negative response. There was a significant influence in the experimental class student's attitudes while the control group showed small changes.

The profile of student religious tolerance towards minority Islamic schools 
Table 5

The results of pre-test and post-test (\%) of students' religious tolerance in the experimental and control classes of minority Islamic schools

\begin{tabular}{|c|c|c|c|c|c|}
\hline \multirow{2}{*}{ No. } & \multirow{2}{*}{ Items of tolerance towards minority Islamic schools } & \multicolumn{2}{|c|}{$\begin{array}{l}\text { Experiment } \\
\text { classes }(\%)\end{array}$} & \multicolumn{2}{|c|}{ Control classes $(\%)$} \\
\hline & & Pre-test & Post-test & Pre-test & Post-test \\
\hline 1. & $\begin{array}{l}\text { The only true Islam is Sunni, while the Shi'ites are a } \\
\text { heretical group. }\end{array}$ & 39.6 & 77.4 & 43.0 & 55.7 \\
\hline 2. & Ahmadiya is not Islam. & 27.4 & 80.4 & 30.4 & 46.1 \\
\hline 3. & $\begin{array}{l}\text { Ahmadiya followers do not deserve to live in } \\
\text { Indonesia. }\end{array}$ & 51.3 & 90.4 & 58.7 & 63.0 \\
\hline 4. & $\begin{array}{l}\text { Ahmadiya followers are infidel because they believe } \\
\text { in Prophet Mirza Gulam Ahmad. }\end{array}$ & 16.5 & 63.9 & 17.8 & 31.3 \\
\hline 5. & $\begin{array}{l}\text { To me, Ahmadiya is Islam, not because it supports } \\
\text { liberal Islam }\end{array}$ & 28.3 & 75.2 & 30.9 & 45.2 \\
\hline 6. & $\begin{array}{l}\text { Ahmadiya has the right to build mosques in } \\
\text { Indonesia. }\end{array}$ & 25.7 & 74.8 & 31.7 & 40.4 \\
\hline 7. & $\begin{array}{l}\text { The Indonesian Ulema Council (MUI) has rightly } \\
\text { convicted Ahmadiya as outcasts. }\end{array}$ & 14.3 & 59.6 & 16.5 & 23.5 \\
\hline 8. & I think Ahmadiya is still classified as Islam. & 25.7 & 76.5 & 29.6 & 41.3 \\
\hline 9. & $\begin{array}{l}\text { I support the Amman Treatise which states that Shì } \\
\text { is similar to Sunni, and are both Islamic groups. }\end{array}$ & 47.8 & 88.7 & 50.0 & 51.7 \\
\hline 10. & $\begin{array}{l}\text { I agree with Prof. KH Din Syamsudin who stated that } \\
\text { Shi a is Islam because it is in the circle of creeds. }\end{array}$ & 56.5 & 84.8 & 59.6 & 66.5 \\
\hline 11. & $\begin{array}{l}\text { I do not believe that the Shi`a glorify Ali ibn Abu } \\
\text { Talib more than the Prophet. }\end{array}$ & 43.9 & 51.7 & 49.1 & 51.3 \\
\hline 12. & $\begin{array}{l}\text { In my opinion, only Shi a takfiri are the kafirs of the } \\
\text { Prophet's companions }\end{array}$ & 44.3 & 83.5 & 48.7 & 54.8 \\
\hline 13. & $\begin{array}{l}\text { I agree with Prof. KH Said Aqil Siraj stated that Shi`a } \\
\text { is similar to Sunni and they are both Muslims. }\end{array}$ & 50.0 & 88.7 & 51.7 & 57.8 \\
\hline 14. & $\begin{array}{l}\text { The Pillars of Faith Shi`a not mentioning Angels } \\
\text { indicates that Shi`a does not believe in them. }\end{array}$ & 29.1 & 67.0 & 37.4 & 38.3 \\
\hline 15. & $\begin{array}{l}\text { The Shi a believe in } 12 \text { Imams, which indicates that } \\
\text { they are heretical. }\end{array}$ & 32.6 & 72.2 & 30.4 & 34.3 \\
\hline 16. & $\begin{array}{l}\text { I agree with Prof. Quraish Shihab that the Shi a } \\
\text { believe in the } 6 \text { pillars of faith and practice the } 5 \text { of } \\
\text { Islam. }\end{array}$ & 64.3 & 86.1 & 65.7 & 70.9 \\
\hline 17. & $\begin{array}{l}\text { I agree with a group of Muslims who like to dissolve } \\
\text { the Shi'a's Ahura Day. }\end{array}$ & 43.0 & 77.8 & 42.6 & 47.0 \\
\hline 18. & $\begin{array}{l}\text { The Shiites should be allowed to build mosques and } \\
\text { Islamic boarding schools in West Java. }\end{array}$ & 23.5 & 68.7 & 24.3 & 24.8 \\
\hline 19. & $\begin{array}{l}\text { To me, Wahabi, Sunni, and Shi`a are equal and are } \\
\text { Muslims. }\end{array}$ & 51.7 & 90.0 & 53.9 & 57.8 \\
\hline 20. & $\begin{array}{l}\text { I agree with some of the famous Da is who badmouth } \\
\text { Shi a. }\end{array}$ & 62.5 & 87.0 & 65.2 & 70.4 \\
\hline 21. & $\begin{array}{l}\text { I want Sunnis and Shiites to build true Islamic } \\
\text { brotherhood. }\end{array}$ & 51.7 & 86.1 & 57.8 & 60.0 \\
\hline
\end{tabular}

$\mathrm{n}$ experiment $=230$ students, $\mathrm{n}$ control $=230$ students

Table 5 shows that before the PAI lecture in August 2020, 7 and 8 items in the experimental and control classes received a positive response from more than $50 \%$ of the total students while 13-14 negative. After November 2020, 21 and 11 items in the 
experimental and control class received a positive response from more than $50 \%$ of the students. The control class had still 10 items that received negative responses, as explained below.

- Before the PAI lecture, more than $50 \%$ of the total students respondent positively to 7-8 Items, including 3, 10, 13-16, and 19-21, except No.9 from the control group. Therefore, more than half of the respondents think that the only true Islam is Sunni and Shi a and Ahmadiya are heretical infidels.

- Before the PAI lecture, more than half of students from both groups responded negatively to the 13-14 items, including No. 1,2, 4-9, 11,12,17 and18 except for 9 in the control group. This means that almost $75 \%$ of students think that minority school adherents have the right to live in Indonesia. Furthermore, KH Said Aqil Sirah, KH Din Syamsudin, and KH Habib Quraisy Shihab or Shi a teachings are similar to Sunnis. Also, students want the establishment of a true Islamic ukhuwah between Sunni-Shi a and Wahhabi.

- After PAI lecture, more than half of the experimental and control class students responded positively 21 and 11 items, respectively. Therefore, there was significant change in the attitude of the experimental class students but not in the control group.

\section{The impact of the change in the PAI curriculum on religious tolerance}

Table 6

Mean of experiment group, mean of control group, and t-test of students religious tolerance

\begin{tabular}{lllll}
\hline Group & Mean 1 & Mean 2 & t-test & Remark \\
\hline 1. Post-pre experiment & 32.39 & 19.59 & 25.527 & Significant at alpha 0.01 \\
\hline 2. Post-pre control & 21.93 & 20.14 & 10.060 & Significant at alpha 0.01 \\
\hline 3. Pre experiment-control & 19.59 & 20.14 & -.711 & Not significant \\
\hline 4. Post experiment-control & 32.39 & 21.93 & 13.972 & Significant at alpha 0.01 \\
\hline 5. Experiment-control gain & 12.80 & 1.80 & 21.630 & Significant at alpha 0.01 \\
\hline n experiment $=$ 230 students, $n$ control = 230 students, & &
\end{tabular}

Table 6 shows that the experimental and conventional PAI teaching materials improve student religious tolerance by $\mathrm{t}=25,527$ and 10,060 which are significant at alpha .01 and df 229. Initially, the two groups had a relatively similar mean tolerance score, specifically 19.59 and 20.14 or $\mathrm{t}=-.711$ which was not significant at alpha 0.05 and $\mathrm{df}$ 229. After college in November 2020, the experimental class score increased to 32.39 was at 21.93 which shows that $t=10.060$ and is significant at alpha $0.01 \mathrm{df} 229$. This difference was confirmed by the gain test using $t=21,630$, specifically significant at alpha $0.01 \mathrm{df} 229$. Therefore, the inclusive PAI model is more effective in increasing students' religious tolerance than conventional teaching materials.

The results of religious tolerance against other religions and minority Islamic schools are shown in Tables 7 and 8 . 
Table 7

Mean of experiment group, mean of control group, and t-test of student's tolerance to other religions

\begin{tabular}{lllll}
\hline Group & Mean 1 & Mean 2 & t-test & Remark \\
\hline 1. Post-pre experiment & 16.03 & 11.26 & 21.497 & Significant at alpha 0.01 \\
\hline 2. Post-pre control & 11.61 & 11.24 & 6.591 & Significant at alpha 0.01 \\
\hline 3. Pre experiment-control & 11.26 & 11.24 & .056 & Not significant \\
\hline 4. Post experiment-control & 16.03 & 11.61 & 11.264 & Significant at alpha 0.01 \\
\hline 5. Experiment-control gain & 4.82 & .37 & 19.336 & Significant at alpha 0.01 \\
\hline
\end{tabular}

$\mathrm{n}$ experiment $=230$ students, $\mathrm{n}$ control $=230$ students,

Table 7 shows that the inclusive and conventional PAI teaching models increase students' religious tolerance towards other religions or $\mathrm{t}=21,497$ and 6,591 significant at alpha .01 and df 229 . Initially, the two groups had a relatively similar mean tolerance score, specifically 11.26 and 11.24 which showed that $t=.056$ and was not significant at alpha 0.05 and df 229. After college, the experimental class score increased to16.03 while the control group had only11.61 which is shown by $\mathrm{t}=6,591$ or significant at 0.01 $\mathrm{df}$ alpha 229. This difference was confirmed by the gain test using $\mathrm{t}=19,336$ or significant at alpha $0.01 \mathrm{df} 229$. Therefore, the inclusive PAI teaching material model is more effective in increasing students' religious tolerance towards other religions.

Table 8

Mean of experiment group, mean of control group, and t-test of students tolerance to Madhab minority

\begin{tabular}{lllll}
\hline Group & Mean 1 & Mean 2 & t-test & Remark \\
\hline 1. Post-pre experiment & 16.30 & 8.33 & 23.415 & Significant at alpha 0.01 \\
\hline 2. Post-pre control & 10.32 & 8.90 & 8.953 & Significant at alpha 0.01 \\
\hline 3. Pre experiment-control & 8.33 & 8.90 & -1.417 & Not significant \\
\hline 4. Post experiment-control & 16.30 & 10.32 & 13.974 & Significant at alpha 0.01 \\
\hline 5. Experiment-control gain & 7.98 & 1.43 & 18.102 & Significant at alpha 0.01 \\
\hline n experiment = 230 students, $n$ control = 230 students, &
\end{tabular}

$\mathrm{n}$ experiment $=230$ students, $\mathrm{n}$ control $=230$ students,

Table 8 shows that the experimental and conventional PAI teaching models improve students' religious tolerance towards minority Islamic schools $(t=23,415$ and 8,953 significant at alpha .01 and df 229). Before college, the two groups had a relatively similar mean tolerance score, particularly 8.33 and 8.90 which was shown by $\mathrm{t}=-1.417$ and was not significant at alpha 0.05 and df 229. In November 2020 the experimental and control classes had mean scores of 16.30 and 10.32 shown by $t=8,953$ which is significant at $0.01 \mathrm{df} 229$ alpha. This difference was confirmed using the gain test using $\mathrm{t}=18,102$ or significant at alpha $0.01 \mathrm{df} 229$. Conclusively, the inclusive PAI teaching material model is more effective increasing student religious tolerance towards minority Islamic schools.

\section{DISCUSSION}

Most students thought adherents of non-Islamic religions and minority schools have a right to live in Indonesia and could be friends or neighbors with them. This was in line 
with Indonesian Christian students who are ready to have formal friendships with followers of other religions, but only a few are ready to have special relationships such as marriage (Suleeman, 2016). The Center for Religious and Cross-Cultural Studies of Gadjah Mada University found that $95.4 \%$ of respondents recognized the importance of religious tolerance in Indonesia. However, normative acceptance does not necessarily imply tolerance in daily interactions (CRCS-UGM, 2008). The pre-test results prove that students will not vote for non-Muslim regional heads in their areas. They also reject minority Islamic schools that develop their teachings and agree with groups that obstruct and disband religious activities. This is in line with the findings of (The-Wahid-Institute, 2011), which stated that there has been an increase in violations of freedom of religion and belief in various regions in Indonesia, such as prohibition or restriction of activities. According to (Puslitbang-Kemenag, 2019), 50.03\% of 13,600 respondents from 34 provinces throughout Indonesia of respondents stated that they were willing to visit houses of other religious followers. The West Java province is the most intolerant region for the past 12 years. There were at least 629 incidents related to violations of freedom of religion and belief in this province (Setara-Institute, 2019). According to Wahid Institute (2014), there are several reported cases of religious intolerance, including church and Ahmadiya mosques sealing, attacking and anti-Shi a declarations. A CSIS study in 23 provinces found that even though individuals live in the same neighborhood, $68.2 \%$ reject the construction of houses of worship for other religions (Suleeman, 2016). Furthermore, $38 \%$ of Muslim students in Jakarta reject non-Muslim teachers (Yasmine et al., 2007).

The results showed that inclusive PAI teaching material is much more effective in increasing students' religious tolerance than the conventional model. This is in line with Rahmat et al. (2019) and Rahmat et al. (2021), which stated that the learning models based on the Qur'ān and typology of schools have succeeded in increasing students' religious tolerance. This is because the two learning models use PAI teaching materials full of religious tolerance and anti-radicalism characteristics. The first model uses teaching materials that are inclusive to other religions while the second caters for minority Islamic sects. According to Rahmat et al. (2016) and (Rahmat \& Fahrudin, 2018b), innovative learning models are more successful in increasing students' religiosity and acceptance. This is also in line with Sunan Drajat Islamic College of Religion research, which stated that the main cause of religious radicalism in the Lamongan Regency is the recitation of radical content. After peaceful Islamic deradicalization teachings, the village is no longer a contributor to terrorism (Lutfiyah et al., 2016). Therefore, inclusive teaching materials are influential on religious tolerance.

This research shows how important textbooks' development is for attitude formation, thinking skills, and knowledge. According to students, the Pancasila Education textbook based on Bhinneka Tunggal Ika ${ }^{1}$ - another compulsory subject apart from PAI - is

${ }^{1}$ Bhinneka Tunggal Ika (Unity in Diversity) is one of the 4 pillars of the nationality of the Republic of Indonesia. The development of the Unity in Diversity-based Pancasila Education textbook model was intended to strengthen a commitment as a pluralistic nation and reinforce the idea that Unity in Diversity, which represents the state's soul and character, must be ingrained in the life of the nation-state of Indonesia 
considered appropriate and capable of raising awareness of diversity among students (Abdulkarim et al., 2020). Syntax textbook adopting a learning model with the contextual approach is more effective than the one with a conventional model (Wahyuni et al., 2018). The Group Science Learning model by the expert judgment improves collaborative problem-solving, science process and self-confidence of primary school teacher candidates (Alfin et al., 2019). Errington \& Bubna-Litic examined 30 management textbooks. The results showed that most popular management textbooks potentially inhibit or weakly support the development of students' capacity for critical thinking. They recommend the need to improve management textbooks (Errington \& Bubna-Litic, 2015). The development of historical thinking in primary and secondary school students in Colombia is not reflected in the Saber 11 Test organized by the State. The questions still measure memorization (low cognitive level). Apart from multiplechoice questions, the historical thinking test needs to include other types of questions involving an analytical review of sources to obtain evidence, construct oral stories and reasoned explanations and narratives. This helps determine the levels of learning in terms of causal relationships, the creation of simple and complex causal chains, and contextualized inferential knowledge. It is essential because of the need for additional instruments to measure more complex cognitive skills (Mena, 2021). According to international studies, textbooks affect student achievement in mathematics. Many researchers have compared textbooks from different countries to select the best ones in their countries (Alabdulaziz \& Higgins, 2021).

Joyce \& Weil (2020) stated that PAI teaching material is an effective learning model because it is included in family information theory. Also, it is proven to be successful in increasing religious tolerance in experimental classes. The preparation of this model fulfills the elements of comprehensiveness, including being sensible, simple, thorough, complete, useful, and tested (Groccia, 2012; Huberman \& Miles, 1994; Wikipedia, 2020; Conference-Al-Azhar, 2020). Generally, the model is complete, useful, tested, makes sense, thorough and simple because it covers all aspects of religious intolerance, it successfully based on strong and clear Al-Qur'ān and hadith arguments. Furthermore, the t-test proved that the t-score was high and significant. This implies that writing PAI textbooks need to present Islam in a correct, comprehensive, and moderate manner based on the study of all verses of the Koran on the same theme and authentic hadiths and authoritative scholars' views. Some moderate Islamic scholars should be asked to judge the contents of the textbooks as students assess legibility and its effect on their religiosity and religious tolerance.

\section{CONCLUSION}

The use of inclusive PAI teaching materials successfully increases religious tolerance and prevents the causes of student religious radicalism. Before college, $47 \%$ and $70 \%$ of

(Abdulkarim et al., 2020). This textbook is expected to raise the awareness of the values of Bhinneka Tunggal Ika, so that students have sensitivity in dealing with social symptoms and problems rooted in differences in ethnicities, races, religions, and values that occur in the community (Farisi, 2014 and Awaru, 2016 in Abdulkarim et al., 2020). 
students were very intolerant of followers of non-Islamic religions and minority Islamic schools. They accused non-Muslims, Shi 'a, and Ahmadiya of being infidels and experts of hell and refused to nominate regional heads. Furthermore, students could not allow them to hold religious activities and build houses of worship in their area. The students also agreed to the actions of Takfiri Salafis, who carried out violence by dissolving Shi a and Ahmadiya religious activities, though they were willing to be friends and neighbors to them. After 10 lectures, there was a sharp decrease in religious intolerance to $16 \%$ and $14 \%$. However, the control classes were still high, specifically $44 \%$ and $53 \%$.

Misreading and references is the main cause of students' intolerance, with their reading being intolerant to social media. Additionally, the Takfiri Salafis were very diligent in entering the campus and influenced students' intolerant mindset. Takfiri Salafis and social media have condemned non-Muslims and minority Islamic schools as infidels. They also build hate speech and promote the notion that non-Muslims and minority Islamic schools have no right to carry out communal religious activities or occupy strategic government positions in Muslim-majority areas.

PAI courses are very strategic in changing the wrong religious mindset of students. Unfortunately, PAI books, including those published by the government, have a minimal religious tolerance content. Naturally, students are intolerant. The inclusive PAI teaching materials compiled have proved to be effective in increasing religious tolerance and limiting the causes of religious radicalism. However, $16 \%$ and $14 \%$ of respondents are consistently intolerant of followers of non-Muslim religions and minority Islamic schools, respectively. Future studies need to explore the reasons for intolerance among students despite receiving inclusive PAI teaching materials and attending lectures in the same class with the same lecturers.

\section{ACKNOWLEDGEMENT}

Author would like to express my special thanks and gratitude to Rector Universitas Pendidikan Indonesia [Indonesia University of Education] and Deputi Bidang Penguatan Riset dan Pengembangan, Kementerian Riset dan Teknologi/Badan Riset dan Inovasi Nasional [the Deputy for Strengthening Research and Development, Ministry of Research and Technology/National Research and Innovation Agency] who provided me useful financial support to complete this wonderful project.

\section{REFERENCES}

Abdillah, M. (2016). Kerukunan Umat Beragama di Era Jokowi-JK. Retrieved from: http://graduate.uinjkt.ac.id.

Abdulkarim, A., Komalasari, K., Saripudin, D., Ratmaningsih, N., \& Anggraini, D. N. (2020). Development of a unity in diversity-based pancasila education textbook for indonesian universities. International Journal of Instruction, 13(1), 371-386. https://doi.org/10.29333/iji.2020.13125a.

Abudawud, I. (2013). Sunan Abu Dawud. In www.lidwapusaka.com.

Addariny, M. (2015). Para Ulama Sepakat Menolak Pemahaman Syiah Imamiyyah. 
Retrieved from: https://muslim.or.id/25405, January 25, 2016.

Ahmad, M. (2006). Pemikiran murtadha muthahhari tentang keadilan ilahi. Al-Fikra: Jurnal Ilmiah Keislaman, Vol. 5(No. 2, Juli-Desember 2006), 292-348.

Alabdulaziz, M. S., \& Higgins, S. (2021). The compatibility of developed mathematics textbook content in Saudi Arabia with NCTM standards: A critical review. International Journal of Instruction, 14(2), 461-482.

Alfin, J., Fuad, A. Z., Nur, M., Yuanita, L., \& Prahani, B. K. (2019). Development of Group Science Learning (GSL) Model to Improve the Skills of Collaborative Problem Solving, Science Process, and SelfConfidence of Primary Schools Teacher Candidates. International Journal of Instruction, 12(1), 147-164. https://doi.org/https://doi.org/10.29333/iji.2019.12110a.

Amal, M.K. (2020). Anti-Shia mass mobilization in Indonesia's democracy: godly alliance, militant groups and the politics of exclusion. IJIMS: Indonesian Journal of Islam and Muslim Societies, 10(1), 25-48. https://doi.org/10.18326/ijims.v10i1.25-48

Anshori, A. (2019). Non-Muslim Ya Kafir. Retrieved from: https://muslim.or.id, Maret 9, 2019.

BBC-News. (2011). Survei: hampir 50\% pelajar setuju tindakan radikal. Retrieved from: https://www.bbc.com/indonesia/berita_indonesia/2011/04/110426, April 26, 2011.

Bukhari, I. (2013). Șahīh Al-Bukhari. In www.lidwapusaka.com).

Conference-Al-Azhar. (2020). Konferensi Ulama Internasional Al-Azhar Hasilkan 29 Rumusan Pembaharuan Pemikiran Islam. Retrieved from: https://kemenag.go.id.

CRCS-UGM. (2008). Annual report on religious life in Indonesia. Center for Religious and Cross-Cultural Studies Universitas Gajah Mada.

Decree of the Director-General of Higher Education, (2020).

Errington, A., \& Bubna-Litic, D. (2015). Management by textbook: The role of textbooks in developing critical thinking. Journal of Management Education, 39(6), 774-800. https://doi.org/10.1177/1052562915594839.

Farah, N. (2016). Konsep Ahl Al-Kitab Menurut pemikiran rasyid ridha dalam tafsir AlManar. Rausyan Fikr, 12(2), 221-249.

Firdaus, E., \& Rahmat, M. (2016). Studi model pembinaan toleransi beragama dalam pembelajaran PAI untuk meningkatkan kerukunan hidup beragama bagi siswa SMA di Kota-kota besar dan multi etnik. Research Report, Universitas Pendidikan Indonesia, Bandung.

Firdaus, E., \& Rahmat, M. (2020). Pengembangan model perkuliahan studi agamaagama berbasis al-qur 'ān dalam perkuliahan pai untuk meningkatkan kerukunan hidup dan pluralisme beragama pada mahasiswa (Penelitian Multy Years, tahun kedua 2020). 
Research Report, Universitas Pendidikan Indonesia, Bandung.

Gabrillin, A. (2016). Laporan Setara Institute: Pelanggaran Kebebasan Beragama Meningkat pada 2015. Retrieved from: https://nasional.kompas.com, January 18, 2016.

Groccia, J. E. (2012). A model for understanding university teaching and learning. In Handbook of College and University Teaching: A Global Perspective (pp. 2-15).

Huberman, A. M., \& Miles, M. B. (1994). Data management and analysis methods. In N. K. Denzin \& Y. S. Lincoln (Eds.), Handbook of qualitative research (pp. 428-444). Sage Publications, Inc.

Ibnumajah, I. (2013). Sunan Ibnu Majah. In www.lidwapusaka.com.

Imarah, M. (1999). Islam dan Pluralitas: Perbedaan dan Kemajemukan dalam Bingkai Persatuan. Terjemahan Abdul Hayyie al-Kattani dari Al-Islam wa at-Ta'addudūdiyah. Gema Insani Press.

Joyce, B., \& Weil, M. (2020). Models of Teaching (9th Edition). Prentice-Hall, Inc.

Komnas-HAM. (2018). Intoleransi Mengancam Hak Asasi Manusia. Retrieved from: https://www.komnasham.go.id/index.php/news/2018/10/30/659/, October 30, 2018.

Komnas-HAM. (2020). Komnas HAM: Pelanggaran kebebasan beragama cukup mengkhawatirkan. Retrieved from: https://www.alinea.id/nasional/komnas-hampelanggaran-kebebasan-beragama-mengkhawatirkan-B1ZWG9ysr, November 6, 2020.

Koran-Tempo. (2019). Intoleransi Pelajar dan Mahasiswa DKI Menguat: Buku teks agama bernuansa radikal menyebar di sekolah taman kanak-kanak Islam. Retrieved from: https://koran.tempo.co/read/metro/439285, January 23, 2019.

Kuntoro. (2011). Metode Statistik (Second edition). Pustaka Melati.

Kurniawan, K. N. (2018). Tolerance Education in the Hidden Curriculum: A Case Study on Indonesian Public School. Masyarakat: Jurnal Sosiologi, 23(1), 1-30. https://doi.org/10.7454/M.

Little, D. (2017). Human Rights, Religious Freedom, and Peace. In 2016 BYU L. Rev. 1215 (2017). Retrieved from: https://digitalcommons.law.byu.edu/lawreview/vol2016/iss4/6.

Lutfiyah, L., Tamam, A. B., \& Muniroh, A. (2016). Deradikalisasi Pemahaman AlQur’ān: Pendampingan Masyarakat Rawan Terpengaruh Gerakan Islam Garis Keras. Mutawâtir: Jurnal Keilmuan Tafsir Hadis, 6(1), 85-112.

Mardani. (2017). Pendidikan Agama Islam untuk Mahasiswa di Perguruan Tinggi (Pertama). Depok, Indonesia: Kencana.

Marshall, P. (2018). The Ambiguities of Religious Freedom in Indonesia. The Review of Faith \& International Affairs, 16(1), 85-96. https://doi.org/10.1080/15570274.2018.1433588 
Mena, N. P. (2021). The Development of Historical Thinking in Colombian Students: A Review of the Official Curriculum and the Saber 11 Test. International Journal of Instruction, 14(1), 121-142. https://doi.org/10.29333/iji.2021.1418a

Mirchandani, K., \& Tastsoglou, E. (2000). Towards a Diversity Beyond Tolerance. Studies in Political Economy, 61(1), 49-78.

Muhtarom, A. (2017). The Study of Indonesian Moslem Responses on Salafy-Shia Transnational Islamic Education Institution. Islam Futura, 17(1), 73-95. https://doi.org/10.22373/jiif.v17i1.1645.

Muslim, I. (2013). Șahīh Muslim. In www.lidwapusaka.com.

Nasution, H. (2006). Bank Makalah: Harun Nasution dalam Seminar di Masjid IAIN Medan 11 Maret 2006. Oleh Hartono Ahmad Jaiz. Retrieved from: https://udhiexz.wordpress.com/tag/pemikiran-harun-nasution/.

Nurwardani, P., Syahidin, Alba, C., Rahmat, M., \& Al, E. (2016). Pendidikan agama Islam: buku ajar mata kuliah wajib umum. Direktorat Jenderal Pembelajaran dan Kemahiswaan, Kementerian Riset, Teknologi, dan Pendidikan Tinggi Republik Indonesia.

Oktaviani, M. A., \& Notobroto, H. B. (2014). Perbandingan tingkat konsistensi normalitas distribusi metode Kolmogorov-Smirnov, Lilliefors, Shapiro-Wilk, dan Skewness-Kurtosis. Jurnal Biometrika Dan Kependudukan, 3(2). http://journal.unair.ac.id/download-fullpapers-biometrikd8bc041810full.pdf

Olsson, S. (2020). “True, Masculine Men Are Not Like Women!”: Salafism between Extremism and Democracy. Religions, 11(3), 118. https://doi.org/10.3390/rel11030118.

Puslitbang-Kemenag. (2019). Survei Indeks Kerukunan Umat Beragama di Indonesia Tahun 2018. Retrieved from: Puslitbang Bimas Agama dan Layanan Keagamaan\%0ABadan Litbang dan Diklat\%0AKementerian Agama.

Qur’ān. (2013). Al-Qur`ān dan Terjemahnya (Digital Qur`ān ver 3.1). Kementerian Agama RI.

Rahmat, M. (2012). Corak Berpikir Keagamaan Mahasiswa (Eksklusif, Inklusif, dan Liberal). Taklim: Jurnal Pendidikan Agama Islam, 10(1), 13-37.

Rahmat, M. \& Fahrudin. (2018a). Understanding the Meaning of Khalifah fil Ardhi in the Qur'ān and Implications on Education. IOP Conference Series: Earth and Environmental Science, 145(1). https://doi.org/10.1088/1755-1315/145/1/012121

Rahmat, M., \& Fahrudin. (2018b). the Learning Model of Madhhab Typology NuMuhammadiyah in Islamic Religious Education. International Journal Pedagogy of Social Studies, 3(1), 57-78. https://doi.org/10.17509/ijposs.v3i1.10631

Rahmat, M., Firdaus, E., \& Yahya, M. W. (2019). Creating Religious Tolerance through Qur`ān-Based Learning Model for Religious Education. Jurnal Pendidikan Islam (UIN Sunan Gunung Djati), 5(2), 175-188. https://doi.org/10.15575/jpi.v5i2.6467 
Rahmat, M., Firdaus, E., \& Yahya, M. W. (2021). The Typology of The Sunni-Shia Madhhab: Can It Eliminate Student Hatred Towards Shia? In Review in Al-Jami 'ah: Journal of Islamic Studies.

Rahmat, M., Supriadi, U., \& Fahrudin. (2016). The Development of Sufistic "Core" Character-Based Qur'ānic Stories Learning Model in Islamic Education for the Improvement of the Students' Behavior. Man in India, 96(12), 5099-5111.

Riḍā, R. (1990). Tafsir al-Manār. Haye ah al-Mișriyah.

Rizal, A. S., \& Rahmat, M. (2019). The Impact of Religious Obedience Against Religious Tolerance on Junior High-School Student. International Symposium on Social Sciences, Education, and Humanities, 306(ISSEH 2018), 185-188. https://doi.org/10.2991/isseh-18.2019.42.

Setara-Institute. (2019). Jawa Barat dan DKI Jakarta Jadi Wilayah Paling Intoleran.

Suleeman, E. (2016). Religious Tolerance Values Among Students of Christian Senior High Schools. International Conference on Social and Political Issues (ICSPI 2016). https://doi.org/10.18502/kss.v3i10.2913

Talib, A. T., Gill, S. S., Kawangit, R. M., \& Kunasekaran, P. (2013). Religious Tolerance: The Key between One ASEAN One Community. Life Science Journal, 10(4), 1382-1385.

The-Wahid-Institute. (2011). Laporan Kebebasan Beragama dan Toleransi di Indonesia: Lampu Merah Kebebasan Beragama.

The-Wahid-Institute. (2014). Laporan Tahunan Kebebasan Beragama/Berkeyakinan dan Intoleransi 2014 ""Utang" Warisan Pemerintah Baru.

Tim-Dosen-PAI-UPI. (2016). Pendidikan Agama Islam (Abd. Majid (ed.); Pertama). Departemen Pendidikan Umum, Universitas Pendidikn Indonesia.

Tim-Penyusun. (2015). Pendidikan Agama Islam di Perguruan Tinggi (L. D. Katili (ed.); Ketiga). Pusat Pengembangan Mata Kuliah Umum Universitas Negeri Gorontalo bekerja sama dengan Ideas Publishing. infoideaspublishing@gmail.com

Tirmidzi, I. (2013). Sunan Tirmidzi. In www.lidwapusaka.com.

Ulfa, M. (2013). Mencermati Inklusivisme Agama Nurcholish Madjid. Ejournal.Unida.Gontor.Ac.Id, 11(2).

Wahyudi, C. (2018). Apa yang membuat jemaah Ahmadiyah sembahyang di masjid sendiri, tidak bersama Muslim lain? Retrieved from: https://www.bbc.com/indonesia/dunia-42791329, February 21, 2018.

Wahyuni, T., Suwandi, S., Slamet, S. Y., \& Andayani. (2018). Contextual Approach to the Development of an Indonesian Syntax Textbook in Higher Education in Indonesia. International Journal of Instruction, 11(1), 211-226. https://doi.org/https://doi.org/10.12973/iji.2018.11115a. 
Wikipedia. (2020). Risalah Amman: Fatwa Konferensi Ulama Islam Internasional. Retrieved from: https://id.wikipedia.org/wik

Yahya, M.W.B.H., \& Rahmat, M. (2021). Building Moderate Islamic Thoughts in Indonesian Students Through Dialogue-Argumentative Methods. Academic Journal of Interdisciplinary Studies, 10(3). https://www.richtmann.org/journal.

Yasmine, Indira, D., Mira, O., Wardhani, W., \& Mughis, A. I. (2007). Toleransi dan Identitas Sosial. Dinamika Hubungan Antar Group di DKI Jakarta. Report Research, Department of Sociology FISIP Universitas Indonesia.

Zakiah, Sahmiar, Sahliah, \& Lubis, T. M. (2015). Pendidikan Agama Islam untuk Perguruan Tinggi Umum. Pusat Perkuliahan Laboratorium Ilmu Dasar dan Umum, Universitas Sumatera Utara bekerja sama dengan CV Putra Maharatu.

Zenna, J., \& Pieri, Z. (2017). How much Takfir is too much Takfir? The Evolution of Boko Haram's Factionalization. Journal for Deradicalization, 11(Summer), 281-308. https://journals.sfu.ca/jd/index.php/jd/index. 